九州大学学術情報リポジトリ

Kyushu University Institutional Repository

\title{
Flowering Control of Tuberose (Polianthes tuberosa L.) in Subtropical Conditions
}

Huang, Kuang-Liang

Laboratory of Horticultural Science, Faculty of Agriculture, Kyushu University

Okubo, Hiroshi

Laboratory of Horticultural Science, Faculty of Agriculture, Kyushu University

https://doi.org/10.5109/24073

出版情報：九州大学大学院農学研究院紀要. 39 (3/4)，pp.115-124，1995-03. Kyushu University バージョン：

権利関係 : 


\title{
Flowering Control of Tuberose (Polianthes tuberosa L.) in Subtropical Conditions
}

\author{
Kuang-Liang Huang ${ }^{* 1}$ and Hiroshi Okubo ${ }^{* 2}$ \\ Laboratory of Horticultural Science, Faculty of Agriculture, \\ Kyushu University, Fukuoka 812-81, Japan \\ (Received September 13, 1994)
}

\begin{abstract}
Effects of temperature and the duration of corm storage on flowering and flower quality of tuberose were examined to establish the most practical method for controlled cut flower production in subtropical conditions. Low temperature storage did not increase cut flower production of the crop at all. Storage at $25^{\circ} \mathrm{C}$ increased the loss of water content in the corms, but accelerated sprouting and flowering after planting and improved the quality of cut flowers when compared with low temperature treatments. It is advised that tuberose corms be stored at temperatures higher than $5^{\circ} \mathrm{C}$ for late planting.
\end{abstract}

\section{INTRODUCTION}

Tuberose corms are usually dry-stored at $5^{\circ} \mathrm{C}$ for late planting in Taiwan. As clarified in the previous report (Huang et al., 1995), the storage at $5^{\circ} \mathrm{C}$ only protected the corms from drying up, but it delayed sprouting and flowering and deteriorated the cut flower quality. The results suggest that temperatures higher than $5^{\circ} \mathrm{C}$, which can reduce the storage cost, shorten the days between planting and flowering and increase the cut flower quality, can be applied in commercial production of tuberose.

In this study, various combinations of temperatures and duration of corm storage were examined to establish the most practical method for controlled tuberose cut flower production in a variety of circumstances : in Taiwan, where the biggest demand for this crop occurs in new year season (by lunar calender) ; in subtropical countries, where the crop is very popular and yearround production occurs ; and in tropical countries.

\section{MATERIALS AND METHODS}

Graded corms of tuberose cv. Double, 2 to $2.5 \mathrm{~cm}$ in diameter, harvested in Taiwan in early March 1993, were shipped by air to Kyushu University and stored at 5, 10, 15 or $20^{\circ} \mathrm{C}$ on 14 A pril 1993 for $20,16,12,8$ or 4 weeks and $25^{\circ} \mathrm{C}$ for 20 weeks (Fig. 1). Corms which had undergone temperature treatments for durations shorter than 20 weeks were stored at $25^{\circ} \mathrm{C}$, so that the total storage period for all corms was exactly 20 weeks. Humidity was not controlled at any storage temperature. Water loss in the corms during storage was measured. On 31 August the corms were brought

*1 Present address : National Chia-yi Institute of Agriculture, Chia-yi, Taiwan, Republic of China

*2 To whom correspondence should be addressed 


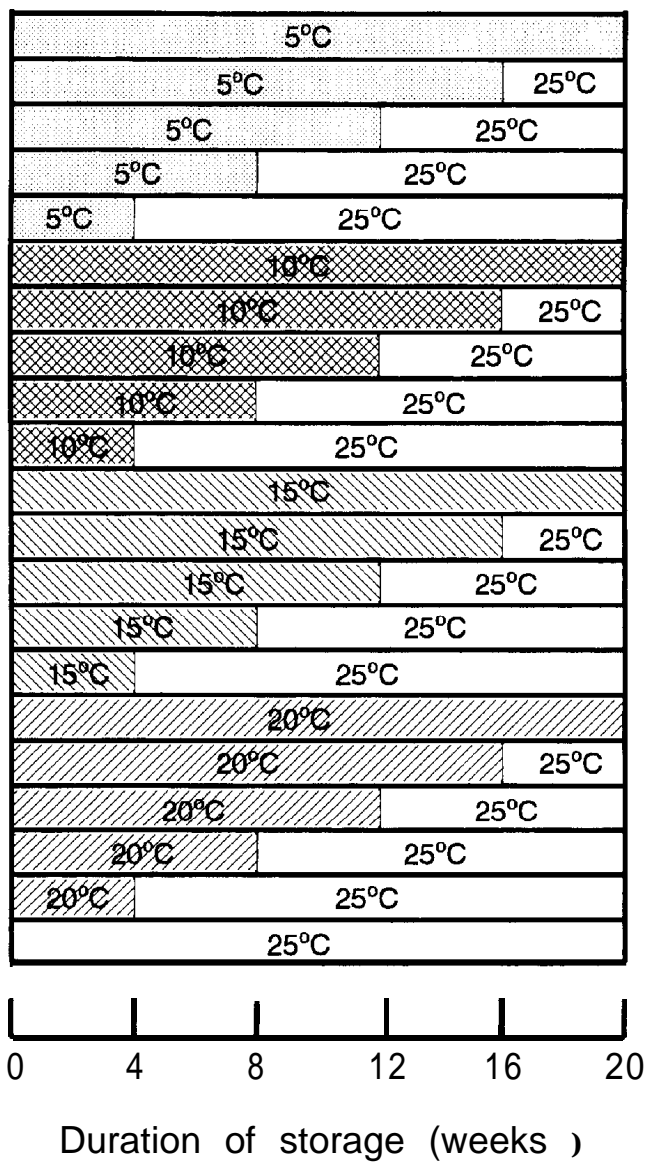

Fig. 1. Experimental design of the combination of storage temperature and duration.

to Taiwan, and on 1 September they were planted in an open field at National Chia-yi Institute of Agriculture (at 23.5" north latitude). The maximum, minimum and average temperatures during the cultivation are shown in Fig. 2.

Flower bud development in the corms was investigated under light microscope on the planting day and every two weeks after planting using 10 corms. The transition from vegetative to flowering conditions was divided into eight stages, in the same manner as described before (Huang et al., 1995) ; I = vegetative, II = onset of flower initiation (apical meristem becomes dome shaped), III =elongation of inflorescence apex, $I V=$ node formation, $V=$ elongation of inflorescence, $V I=$ flower stalk elongation, VII = bolting and VIII = flowering. Growth and flowering characteristics were measured. Subsequent crop management followed standard commercial practice in Taiwan.

The term "corm" is used in this paper, but other terms such as "tuber", "rhizome" and "bulb" are used for the storage organ of this crop. 


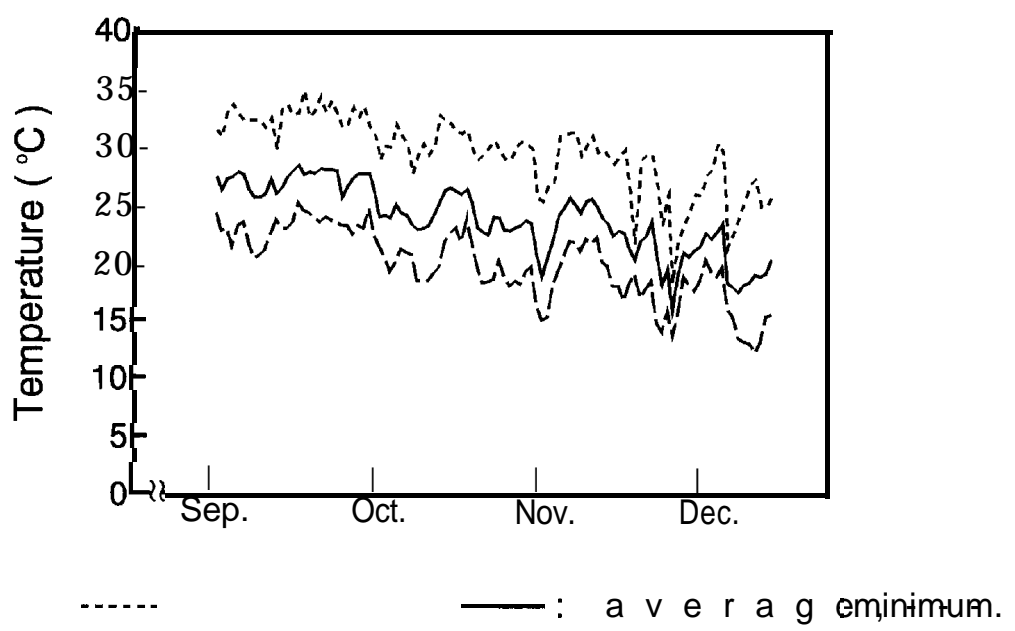

Fig. 2.

during cultivation of tuberose in Chia-yi, Taiwan.

\section{RESULTS}

Water loss during storage

Among the treatments with constant temperatures, the higher the storage temperatures were, the greater the loss of water in the corms was (Fig. 3). The lower the temperatures for initial storage were, and the longer those temperatures were maintained, the greater was the water loss in the corms during storage at $25^{\circ} \mathrm{C}$ (Fig. 4). Water loss occurred more rapidly in the corms stored initially at low temperatures than in the corms which were stored at a constant temperature of $25^{\circ} \mathrm{C}$.

Shoot emergence during storage

The higher the storage temperatures were, and the longer those high temperatures were maintained, the more accelerated was the apical shoot emergence during storage, whereas the lower the initial storage temperatures were, the more the lateral shoot emergence was promoted (Fig. 5). Corms given the treatment of $5^{\circ} \mathrm{C}$ for 20 weeks, never stored at $25^{\circ} \mathrm{C}$, sprouted neither apical nor lateral shoots. No root growth was observed during storage at any treatment.

Flower initiation and development after planting

On 1 September, at planting, the stages of flower development were almost the same in the corms of all treatments, indicating that the storage temperature did not affect the flower development during storage (Fig. 6).

After planting, there was no clear difference in flower development among the corms stored at $20^{\circ} \mathrm{C}$ for various duration. However, the shorter the periods of 5,10 and $15^{\circ} \mathrm{C}$ were, the faster the flower bud developed was. When the storage durations were the same, there were not clear difference in flower development among corms 


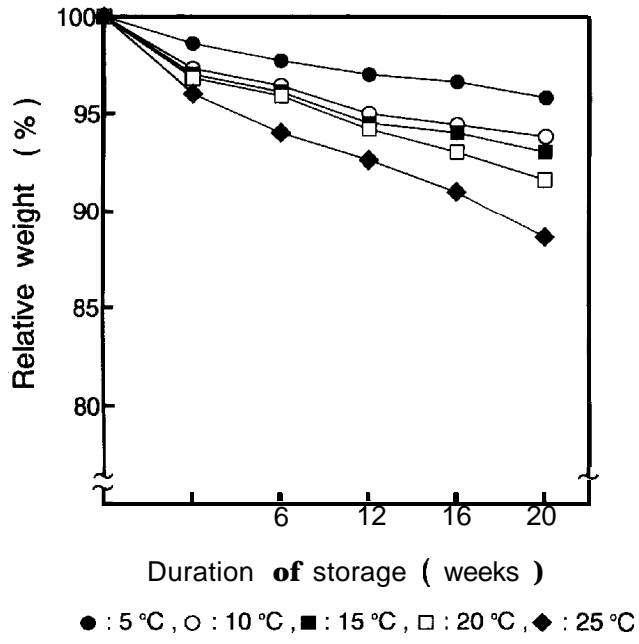

Fig. 3. Effects of storage temperature on water loss in the corms during storage.

stored at different low temperatures.

Sprouting, growth and flowering

The earliest sprouting was observed in the corms stored at $25^{\circ} \mathrm{C}$, and the latest sprouting was recorded by the treatment with $10^{\circ} \mathrm{C}$ for 20 weeks ; the difference between them was 11.7 days. Corms stored at 5,10 and $15^{\circ} \mathrm{C}$ sprouted later, at times roughly proportionate to the duration of storage (Table 1). Among corms stored at constant temperature, the lower the storage temperature was the later the corms sprouted.

The growth in the open field was retarded when the storage temperatures of $5^{\circ} \mathrm{C}$ and $10^{\circ} \mathrm{C}$ occurred for greater duration, but there was no retardation in the corms stored at $20^{\circ} \mathrm{C}$ for any duration (data not shown). There was also no difference between the growth of the corms stored at $25^{\circ} \mathrm{C}$ for 20 weeks and at $5^{\circ} \mathrm{C}$ for four weeks.

Cold treatments for four weeks at any temperature did not affect the days to flowering (Table 1). Beyond four weeks the lower the storage temperatures and the longer the storage periods were, the greater was the number of days between planting and flowering. In the corms stored at 5,10 and $15^{\circ} \mathrm{C}$ for 20 weeks, flowering was 15,14 and 10.5 days later than that of the corms stored at

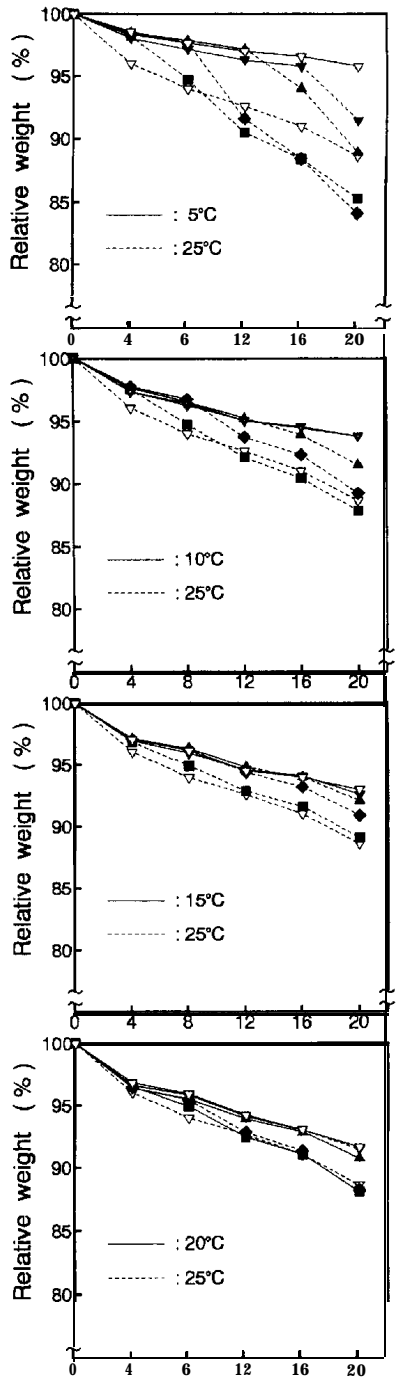

Duration of storage (weeks )

. : 4 weeks, •: 8 weeks, $4: 12$ weeks,

Fig. 4. Effects of storage temperature on water loss in the corms during storage. 


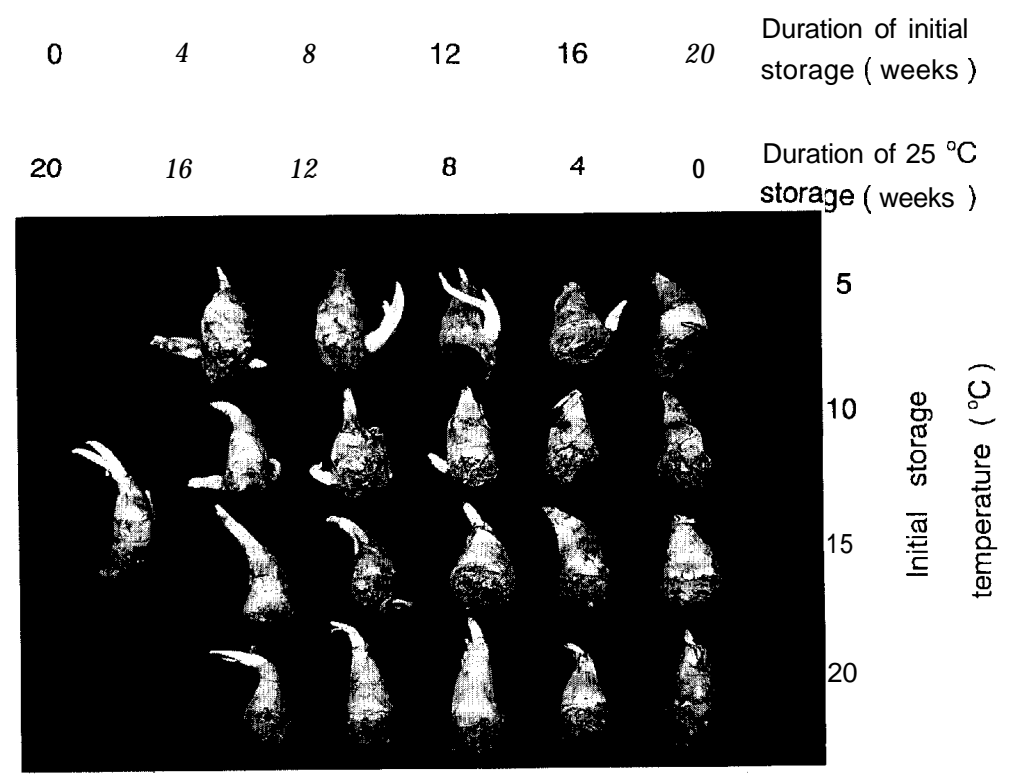

Fig. 5. Effects of storage temperature on sprouting of the corms during storage.

$25^{\circ} \mathrm{C}$ for 20 weeks, respectively.

Flower characteristics

No flowers were taller than those treated at a constant $25^{\circ} \mathrm{C}$ (Table 2). Among the corms stored at constant temperatures, lengths of the flower stalk and inflorescence were the least when the corms were stored at $5^{\circ} \mathrm{C}$. The differences between the treatments were 12.6 and $14 \mathrm{~cm}$, respectively. Number of florets was also reduced by the longer storage at $5^{\circ} \mathrm{C}$. Number of petals was slightly decreased by the storage at $5^{\circ} \mathrm{C}$ and $10^{\circ} \mathrm{C}$ for 20 weeks, but there were no differences among the other treatments. It was also less with the treatment of constant $25^{\circ} \mathrm{C}$ than with the other treatments. Length and width of petals were decreased by the $5^{\circ} \mathrm{C}$ storage for 20 weeks, otherwise there were no significant differences.

\section{DISCUSSION}

Storage at $25^{\circ} \mathrm{C}$ accelerated the water loss more than any other storage temperature, from $5^{\circ} \mathrm{C}$ to $20^{\circ} \mathrm{C}$, when the temperatures were constant. The results are similar to those obtained previously (Huang et al., 1995). However, the water loss was promoted more by the treatments which included a change from low temperature to $25^{\circ} \mathrm{C}$ than by storage at a constant temperature of $25^{\circ} \mathrm{C}$. This is true in spite of the fact that the duration of $25^{\circ} \mathrm{C}$ treatment, which could accelerate the water loss, was shorter than the treatments with temperature shift. Sudden changes and large differences in temperatures may affect the promotion of water loss.

Although the storage at $25^{\circ} \mathrm{C}$ for 20 weeks reduced $11 \%$ of the water in the corms, 


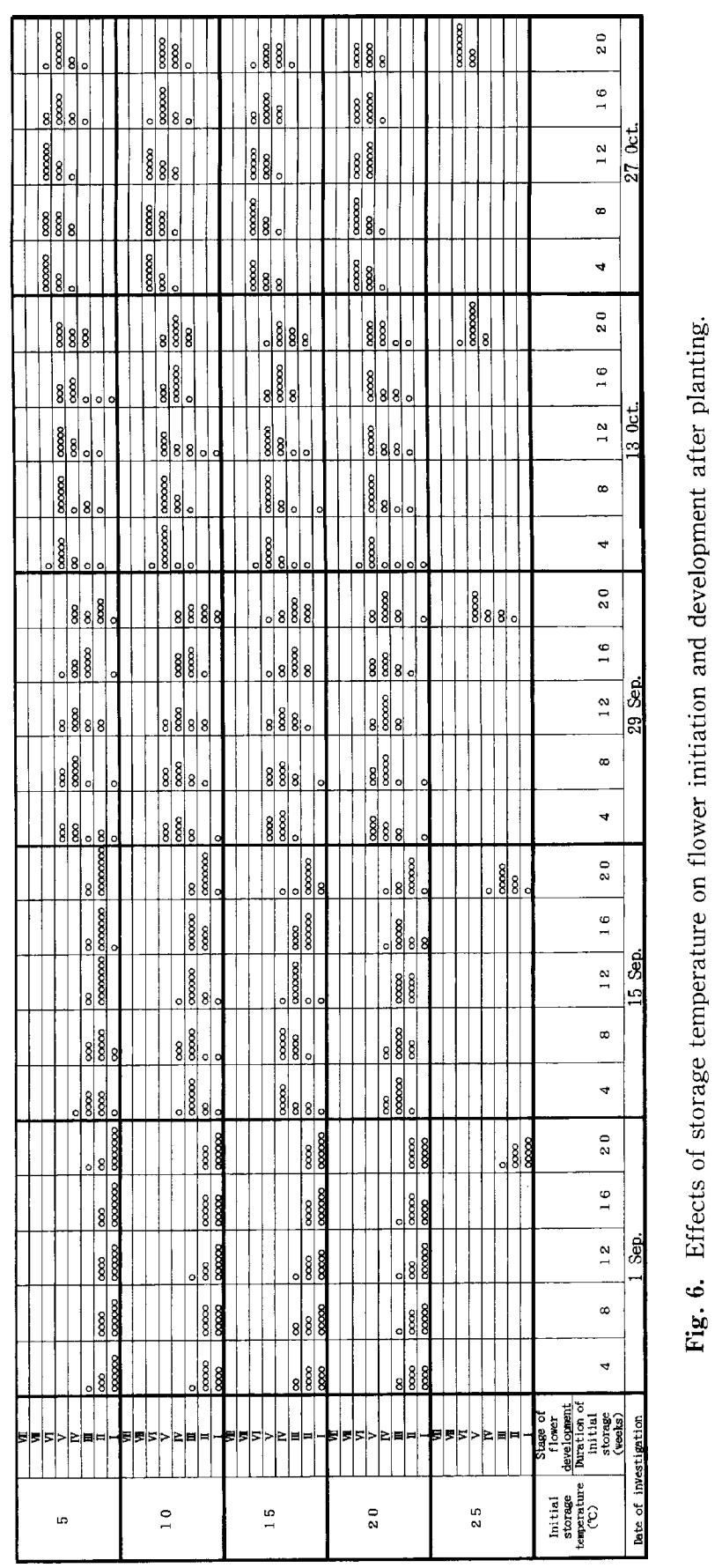


Table 1. Effects of storage temperature on flowering of tuberose corms.

\begin{tabular}{|c|c|c|c|c|}
\hline \multicolumn{2}{|c|}{ Initial storage } & \multirow{2}{*}{$\begin{array}{l}\text { Final } \\
\text { storage } \\
\text { at } 25^{\circ} \mathrm{C} \\
\text { (weeks) }\end{array}$} & \multirow{2}{*}{$\begin{array}{l}\text { Days to } \\
\text { sprouting }\end{array}$} & \multirow{2}{*}{$\begin{array}{l}\text { Days to } \\
\text { flowering }\end{array}$} \\
\hline $\begin{array}{l}\text { Temper- } \\
\text { ature } \\
\left({ }^{\circ} \mathrm{C}\right)\end{array}$ & Weeks & & & \\
\hline 25 & 20 & 0 & $3.6 \mathrm{a}$ & $86.0 \mathrm{ab}$ \\
\hline \multirow[t]{5}{*}{20} & 4 & 16 & $5.2 \mathrm{bcd}$ & $87.4 \mathrm{bcd}$ \\
\hline & 8 & 12 & $4.4 \mathrm{ab}$ & 87.7 bcd \\
\hline & 12 & 8 & $4.5 \mathrm{ab}$ & $88.5 \mathrm{de}$ \\
\hline & 16 & 4 & $5.3 \mathrm{bcd}$ & $88.8 \mathrm{def}$ \\
\hline & 20 & 0 & $5.5 \mathrm{~cd}$ & 91.4 hij \\
\hline \multirow[t]{5}{*}{15} & 4 & 16 & $4.3 \mathrm{a}$ & $85.3 \mathrm{a}$ \\
\hline & 8 & 12 & $5.8 \mathrm{~d}$ & $85.8 \mathrm{a}$ \\
\hline & 12 & 8 & $4.8 \mathrm{bc}$ & $88.1 \mathrm{~cd}$ \\
\hline & 16 & 4 & $5.2 \mathrm{bcd}$ & $91.1 \mathrm{hi}$ \\
\hline & 20 & 0 & $10.0 \mathrm{~g}$ & $96.5 \mathrm{k}$ \\
\hline \multirow[t]{5}{*}{10} & 4 & 16 & $4.3 \mathrm{a}$ & $86.3 \mathrm{ab}$ \\
\hline & 8 & 12 & $4.4 \mathrm{ab}$ & $87.2 \mathrm{bc}$ \\
\hline & 12 & 8 & $5.3 \mathrm{bcd}$ & 89.8 efg \\
\hline & 16 & & $7.7 \mathrm{f}$ & $93.0 \mathbf{j}$ \\
\hline & 20 & 0 & $15.3 \mathrm{i}$ & 100.01 \\
\hline \multirow[t]{5}{*}{5} & 4 & 16 & $4.7 \mathrm{bc}$ & $87.6 \mathrm{bcd}$ \\
\hline & 8 & 12 & $4.9 \mathrm{bcd}$ & $90.1 \mathrm{fgh}$ \\
\hline & 12 & 8 & $5.8 \mathrm{~d}$ & $92.1 \mathrm{ij}$ \\
\hline & 16 & 4 & $6.8 \mathrm{e}$ & $90.6 \mathrm{gh}$ \\
\hline & 20 & 0 & $14.5 \mathrm{~h}$ & 99.01 \\
\hline
\end{tabular}

Mean separation within columns by Duncan's multiple range test, $5 \%$.

the corms were still replantable. Ambient summer temperature in subtropical conditions, as in Taiwan, may cause greater water loss than storage at $25^{\circ} \mathrm{C}$, and it may be concluded that $25^{\circ} \mathrm{C}$ should be the maximum temperature for storage of tuberose corms.

Lateral shoots of a current year's generation are the main shoots of the next generation. Results indicating that low temperature storage promoted the lateral shoot growth, instead of the emergence of the main shoots during storage, may suggest that the low temperatures gave the unfavorable or injurious effects on the main shoots and the growth of lateral shoots took place so that advancement to the next life cycle could replace the growth of the main shoots.

From the results that there were no consistent differences in flower development in the corms at planting, and from the previous report (Huang et al., 1995) that flower development did not proceed during the storage for 20 weeks either at $5^{\circ} \mathrm{C}$ or $25^{\circ} \mathrm{C}$, it is concluded that flower development does not occur until planting in tuberose corms, in accordance with the previous report by Kosugi and Kimura (1960). It is also concluded that tuberose does not require any low temperature for flowering and satisfactory flower quality, as previously reported by Kosugi and Kimura (1960) and Huang et al., (1995). The yearly average temperature in Chia-yi is over $23^{\circ} \mathrm{C}$, which is high enough for flower initiation for which the minimum temperature required is 
Table 2. Effects of storage temperature on flower characteristics of tuberose corms.

\begin{tabular}{|c|c|c|c|c|c|c|c|c|}
\hline \multirow{2}{*}{$\begin{array}{c}\text { Initial } \\
\text { Temper- } \\
\text { ature }\left({ }^{\circ} \mathrm{C}\right)\end{array}$} & storage & \multirow{2}{*}{$\begin{array}{l}\text { Final } \\
\text { storage } \\
\text { at } 25^{\circ} \mathrm{C} \\
\text { (weeks) }\end{array}$} & \multirow{2}{*}{$\begin{array}{l}\text { Flower } \\
\text { stalk } \\
\text { length } \\
(\mathrm{cm})\end{array}$} & \multirow{2}{*}{$\begin{array}{l}\text { Inflores- } \\
\text { cence } \\
\text { length } \\
(\mathrm{cm})\end{array}$} & \multirow{2}{*}{$\begin{array}{l}\text { No. of } \\
\text { florets }\end{array}$} & \multirow{2}{*}{$\begin{array}{l}\text { No. of } \\
\text { petals } \\
\text { per } \\
\text { floret }\end{array}$} & \multirow{2}{*}{$\begin{array}{l}\text { Petal } \\
\text { length } \\
(\mathrm{cm})\end{array}$} & \multirow{2}{*}{$\begin{array}{l}\text { Petal } \\
\text { width } \\
(\mathrm{cm})\end{array}$} \\
\hline & Weeks & & & & & & & \\
\hline 25 & 20 & 0 & $109.3 \mathrm{fgh}$ & $31.7 \mathrm{k}$ & $27.8 \mathrm{fg}$ & $26.2 \mathrm{ab}$ & $3.12 \mathrm{de}$ & $0.86 \mathrm{a}$ \\
\hline \multirow[t]{5}{*}{20} & 4 & 16 & $100.4 \mathrm{~b}$ & $24.7 \mathrm{def}$ & $23.4 \mathrm{~cd}$ & 27.5 cdef & $3.05 \mathrm{de}$ & $0.82 \mathrm{a}$ \\
\hline & 8 & 12 & $102.9 \mathrm{c}$ & 26.7 ghi & $25.3 \mathrm{de}$ & 27.8 cdef & $2.88 \mathrm{~cd}$ & $0.83 \mathrm{a}$ \\
\hline & 12 & 8 & $108.4 \mathrm{fgh}$ & $28.9 \mathrm{ijk}$ & $26.5 \mathrm{efg}$ & $28.8 \mathrm{f}$ & $2.95 \mathrm{~cd}$ & $0.84 \mathrm{a}$ \\
\hline & 16 & 4 & $106.4 \mathrm{def}$ & 27.1 ghi & $27.5 \mathrm{fg}$ & 27.9 cdef & $3.02 \mathrm{de}$ & $0.85 \mathrm{a}$ \\
\hline & 20 & 0 & $108.0 \mathrm{fg}$ & $28.8 \mathrm{ijk}$ & $28.6 \mathrm{~g}$ & $28.4 \mathrm{f}$ & $3.07 \mathrm{de}$ & $0.88 \mathrm{a}$ \\
\hline \multirow[t]{5}{*}{15} & 4 & 16 & 107.0 efg & $30.6 \mathrm{jk}$ & $25.9 \mathrm{def}$ & $26.5 \mathrm{abc}$ & $3.10 \mathrm{de}$ & $0.82 \mathrm{a}$ \\
\hline & 8 & 12 & $107.1 \mathrm{efg}$ & $29.5 \mathrm{ijk}$ & $25.5 \mathrm{def}$ & 27.6 cdef & $2.96 \mathrm{cde}$ & $0.83 \mathrm{a}$ \\
\hline & 12 & 8 & $108.5 \mathrm{fgh}$ & $28.7 \mathrm{hij}$ & $28.1 \mathrm{fg}$ & 27.5 cdef & $3.03 \mathrm{de}$ & $0.86 \mathrm{a}$ \\
\hline & 16 & 4 & $107.8 \mathrm{fg}$ & 26.9 ghi & $26.7 \mathrm{efg}$ & $28.5 \mathrm{f}$ & $3.23 \mathrm{e}$ & $0.87 \mathrm{a}$ \\
\hline & 20 & 0 & $106.0 \mathrm{def}$ & $23.2 \mathrm{cde}$ & $26.9 \mathrm{efg}$ & $27.9 \mathrm{def}$ & $2.84 \mathrm{c}$ & $0.84 \mathrm{a}$ \\
\hline \multirow[t]{5}{*}{10} & 4 & 16 & $108.6 \mathrm{fgh}$ & 27.7 ghij & $24.5 \mathrm{~d}$ & $26.7 \mathrm{abcd}$ & $2.95 \mathrm{~cd}$ & $0.84 \mathrm{a}$ \\
\hline & 8 & 12 & $105.8 \mathrm{de}$ & $29.0 \mathrm{ijk}$ & $25.5 \mathrm{def}$ & 27.5 bcde & $3.01 \mathrm{de}$ & $0.81 \mathrm{a}$ \\
\hline & 12 & 8 & $110.3 \mathrm{gh}$ & $26.3 \mathrm{fgh}$ & $26.0 \mathrm{defg}$ & $28.6 \mathrm{f}$ & $3.13 \mathrm{de}$ & $0.84 \mathrm{a}$ \\
\hline & 16 & 4 & $111.7 \mathrm{~h}$ & $23.6 \mathrm{cde}$ & 27.2 efg & $28.6 \mathrm{f}$ & $3.02 \mathrm{de}$ & $0.86 \mathrm{a}$ \\
\hline & 20 & 0 & $107.1 \mathrm{efg}$ & 25.6 efg & $27.7 \mathrm{fg}$ & 25.9 a & $2.70 \mathrm{~b}$ & $0.82 \mathrm{a}$ \\
\hline \multirow[t]{5}{*}{5} & 4 & 16 & $110.0 \mathrm{gh}$ & 27.6 ghi & $23.3 \mathrm{c}$ & $28.0 \mathrm{def}$ & $3.04 \mathrm{de}$ & $0.86 \mathrm{a}$ \\
\hline & 8 & 12 & $103.6 \mathrm{~cd}$ & $21.0 \mathrm{~b}$ & 19.7 a & $28.7 \mathrm{f}$ & $2.90 \mathrm{~cd}$ & $0.83 \mathrm{a}$ \\
\hline & 12 & 8 & $101.6 \mathrm{c}$ & $22.6 \mathrm{~cd}$ & $21.3 \mathrm{bc}$ & 27.6 cdef & $2.97 \mathrm{cde}$ & $0.86 \mathrm{a}$ \\
\hline & 16 & 4 & $103.6 \mathrm{~cd}$ & $21.9 \mathrm{c}$ & $21.2 \mathrm{~b}$ & 28.2 ef & $2.86 \mathrm{~cd}$ & $0.84 \mathrm{a}$ \\
\hline & 20 & 0 & 96.7 a & $17.7 \mathrm{a}$ & $17.4 \mathrm{a}$ & 25.8 a & $2.37 \mathrm{a}$ & $0.76 \mathrm{a}$ \\
\hline
\end{tabular}

Mean separation within columns by Duncan's multiple range test, $5 \%$.

$13^{\circ} \mathrm{C}$ (Kosugi and Kimura, 1960).

Our results suggest that tuberose corms should be stored at higher temperatures, between $20^{\circ} \mathrm{C}$ and $25^{\circ} \mathrm{C}$, until planting, but care should be taken to protect the corms from drying up during storage at higher ambient temperatures.

Low temperature treatment during corm storage seems to have no effects on flower initiation before and after planting, or on forced maturation in tuberose. This is quite a contrast to the role of low temperature on another tropical geophyte, Hippeastrum hybridum, which is believed to have originated from Mexico, the same area as tuberose (Bailey, 1919). Flowering of Hippeastrum hybridum is accelerated by the storage of the bulbs at low temperatures at $13^{\circ} \mathrm{C}$ for eight to 10 weeks and at $5^{\circ} \mathrm{C}$ to $9^{\circ} \mathrm{C}$ for longer storage (De Hertogh, 1989 ; De Hertogh et al., 1990) ; however, this temperature sequence has been empirically established without physiological understanding (Rees, 1985). Actually, the flowering of the plant is regulated by bulb size ; low temperatures and specific daylengths are not required for flower initiation. Flower initiation occurs alternatively with the formation of four leaves (under warm temperatures and sufficient moisture) without any interruption in growth (Rees, 1972).

Tuberose flowers are very popular in the tropics and subtropics including the Indian continent and Taiwan. Mukhopadhyay and Bankar (1981) planted the corms of tuberose monthly between January and December in India. The highest number of 
spike per plant (2.1 to 2.7) was obtained from April or May planting. To extend harvest time of the crop, extending planting time was investigated (Armitage and Laushman, 1990). Longer harvest duration was observed with an earlier planting in Georgia, U. S. A., but corm storage conditions were not described.

There are some reports on the effects of various growth regulators available which are, however, very much conflicting (Ramaswamy et al., 1979 ; Jana and Biswas, 1979, 1982 ; Basu and Bose, 1980 ; Hassan and Agina,1980a, b ; Mukhopadhyay and Bankar, 1983 ; Biswas et al., 1983 ; Choudhary, 1987 ; Dhua et al., 1987). Commercially, no plant hormones are known to be used at this time, at least not in Japan and Taiwan. Our results indicate that flowering of the crop will be controlled by storing the corms at appropriate temperatures to meet either local or world market demand.

\section{REFERENCES}

Armitage, A. M. and J. M. Laushman 1990 Planting date and inground time affect cut flowers of Liatris, Polianthes, and Iris. HortScience, 25 : 1239-1241

Bailey, L. H. 1919 The Standard Cyclopedia of Horticulture, 3rd ed. MacMillan, London

Basu, T. K. and T. K. Bose 1980 Uses of ancymidol on flowering bulbous plants. Science and Culture, $46: 323-325$

Biswas, J., T. K. Bose and R. G. Maiti 1983 Effect of growth substances on growth and flowering of tuberose (Polianthes tuberosa L.). South Indian Hortic., 31: 1299132

Choudhary, M. L. 1987 Effect of growth regulators on growth and flowering of tuberose (Polianthes tuberosa L.). Ann. Agri. Sci., 32: 1451-1457

De Hertogh, A. A. 1989 Holland Bulb Forcer's Guide, 4th Edition. International Flower-Bulb Centre, Hillegom (The Netherlands)

De Hertogh, A. A., C. Noone and A. Lutman 1990 Hippeastrum. The Geophyte, TM. North Carolina State University, Raleigh, N. C.

Dhua, R. S., S. K. Ghosh, S. K. Mitra, L. P. Yadav and T. K. Bose 1987 Effect of bulb size, temperature treatment of bulbs and chemicals on growth and flower production in tuberose (Polianthes tuberosa L.). Acta Hortic., 205: 121-128

Hartsema, A. M. 1961 Influence of temperatures on flower formation and flowering of bulbous and tuberous plants. In "Encyclopedia of Plant Physiology 16", ed. by W. Ruhland, Springer-Verlag, Berlin, pp. 123-167

Hassan, A. H. and E. A. Agina 1980a The effect of chlormequat (CCC) on the growth and flowering of tuberose. 1. Autumn planting. Ann. Agri. Sci., 12: 211-221

Hassan, A. H. and E. A. Agina 1980b The effect of chlormequat (CCC) on the growth and flowering of tuberose. 2. Summer planting. Ann. Agri.Sci, 13: 145-152

Huang, K. L., I. Miyajima and H. Okubo 1995 Effects of low temperature on flowering in tuberose (Polianthes tuberosa L.). J. Fac. Agr., Kyushu Univ., 39: 105-113

Jana, B. K. and S. Biswas 1979 Effects of growth substances on growth and flowering of tuberose (Polianthes tuberosa L.). Haryana J. Hortic. Sci., 8: 216-219

Jana, B. K. and S. Biswas 1982 Effects of growth regulators on growth and flowering of tuberose (Polianthes tuberosa L.). South Indian Hortic., $30: 163-165$

Kosugi, K. and Y. Kimura 1960 On the flower bud differentiation and flower bud development in Polianthes tuberosa L. Tech. Bull. Fac. Agric., Kagawa Univ., 12: 230-234 (in Japanese)

Mukhopadhyay, A. and G. J. Bankar 1981 Effect of time of planting on growth, flowering and bulb production in tuberose cv. 'Single'. Indian Agriculturist, $25: 131-134$

Mukhopadhyay, A. and G. J. Bankar 1983 Regulation of growth and flowering in Polianthes tuberosa L. with gibberellic acid and ethrel spray. Scientia Hortic., 19: 149-152 
Ramaswamy, N., C. Paulraj and P. Chockalingam 1979 Studies on the influence of growth regulators on flowering and yield of tuberose (Polianthes tuberosa L.). Annamalai Univ. Agri. Res. Annual, 7/8:29-33

Rees, A. R. 1972 The Growth of Bulbs. Academic Press, London

Rees, A. R. 1985 Hippeastrum. In "Handbook of Flowering" Vol. I, ed. by A. Halevy, CRC Press, Boca Raton, Florida, pp. 294-296 